\title{
SOCIAL MEDIA USE AND ACADEMIC PERFORMANCE: A STUDY ON UNDERGRADUATE ACCOUNTING STUDENTS IN BANGLADESH
}

\author{
ZOBAIDA KHANAM
}

Received: 7 October 2019 / Revised: 20 February 2020, 31 March 2020/ Accepted: 12 May 2020 (C) 2020 Faculty of Business and Accountancy, University of Malaya. All rights reserved.

\begin{abstract}
A B S T RACT
Research aim: The paper aims to ascertain the relationship between social media uses and academic performance of undergraduate accounting students in Bangladesh.

Design/Methodology/Approach: This study is based on empirical data gathered from a survey of 154 undergraduate accounting students in Bangladesh. Structural equation modelling (SEM) analysis is applied to make sense of the results of the research questions.

Research findings: The analysis disclosed that five factors are categorised as the reasons for using social media for academic purposes of which online sharing and academic comprehension have a significant positive impact on academic performance (CGPA), whereas the completion of course tasks have a significant negative impact on CGPA or the academic performance. Academic involvement and personal tutorial support do not associate significantly with academic performance (CGPA).

Theoretical contribution/ Originality: Most of the studies on social media focus on the relationship between social media use and educational outcome in general, not concentrating on a particular subject. As regards the subject specificity, the interest and satisfaction of learning accounting course was measured through the use of social media. In Bangladesh, the study of social media use is limited. This analysis concentrates particularly on accounting discipline learning perspective.

Practitioner/ Policy implication: This study identifies different academic uses of social media and defines policies and procedures that will modify the use of social media as learning tools of undergraduate students.

Research limitation: This study considered only 154 undergraduate students in Bangladesh, mainly from the capital city Dhaka. The investigation is limited to the data collected from the survey questionnaire administered to the sampled students.
\end{abstract}

Keywords: Social media use, Accounting students, Academic performance, CGPA

Type of Manuscript: Research paper

JEL Classification: A22, M41, M49

\section{Introduction}

In the present context, technology has facilitated mobile and web-based social media engagement. Over the last decade, social networking sites have become a strong platform in academia due to the affordability and easy access to shared information (Lau, 2017). Users accomplish their day to day requirements through the access of social media sites like Facebook, Twitter, and Myspace (Boyd and Ellison, 2007). Lenhart, Purcell, Smith, and Zickuhr (2010) analysed that around the globe on average 72 per cent of students in college have a profile on social media where 45 per cent of college students sign into a social media site at least

Department of Accounting and Information Systems, Faculty of Business Studies, Bangladesh University of Professionals, Mirpur Cantonment, Dhaka 1216, Bangladesh. Email: zobaida@bup.edu.bd 
once a day. According to the Bangladesh Telecommunication Regulatory Commission (BTRC)'s December 2019 report, the statistics of total number of internet subscribers revealed that Bangladesh has 99.43 million internet users most of whom are engaged with social media (Rahman, 2020). Among them, Facebook has the greatest number of users with approximately 35 million in Bangladesh, constituting 94 per cent of the total monthly active users of all social media throughout the country (Andreshak, 2020).

Considering the above circumstance, at present, many universities in Bangladesh prefer to incorporate the academic curriculum through social media sites such as Facebook pages, Instagram, YouTube or Twitter accounts, etc. This has become a common practice of the university and faculties to create a specific group on a social media where they share all the required academic documents. Ultimately, it helps to centralise the study materials and academic activities (Khan, Kend, \& Robertson, 2016). However, conventionally students are focused on using social media more purposively based on its quantity rather than the quality of its use (Lei \& Zhao, 2007). Though social media usage was not measured from the viewpoint of its outcome, however, researchers emphasise the quality of using social media focusing on its constructive output like how, whom and for what purpose it is being used.

McFarlane (1997, p.4) denotes "Computer use alone, without clear objectives and well-designed tasks, is of little intrinsic value". In light of the above, a country like Bangladesh which is ranked second in number of active Facebook users should focus on the use of different social media sites giving importance to educational objectives (Murad, 2017). Though different studies explored the usage of social networking sites by students and its impact on education (Sponcil \& Gitimu, 2013), there is limited research in Bangladesh regarding social media usage, particularly among accounting students, where the social media is studied along within the purvey of information systems. The primary objective of the study is to assess the academic outcome of social media usage among accounting students. To achieve the primary research objective, the study explores the significant factors for the students in Bangladesh to use social media and the impact of using social media on accounting students' academic achievement CGPA.

The present study will enable accounting students to mark different uses of social media for academic purposes, and the positive outcome will encourage them to take social media as a formal learning platform to accomplish academic tasks effectively. In addition, the study will assist in formulating policies and procedures that will modify the use of social media as learning tools for undergraduate students. The other parts of the paper are as follows: First, the relevant literature is reviewed regarding the usage of social media. Afterwards, the relationship between social media use and academic outcomes is established. Thereafter, the research questions are established. The paper concludes with the scope for future research, implications, and recommendations.

\section{Literature Review}

Social media is known as the technological platform to collaborate and engage a large community and has various formats such as blogs, social networking sites, wikis, community networking (Kaplan \& Haenlein, 2010). There are numerous 
active websites available to connect users. For instance, there are social news and bookmarking sites, including Reddit and Digg, where users can rank different sites through voting based on the importance of content. In the present context of web 2.0, Facebook, Myspace, Instagram, LinkedIn are the dominant mediums for social networking.

The information circulated in social media is used by people to introduce themselves, products and services (Blackshaw \& Nazzaro, 2006). The technological aspects of different social media are similar and consistent with each other, while the culture in operating those media vary (Boyd \& Ellison, 2007). Facebook initiated as a private communication platform for Harvard University students; then the users started to increase, including general people to professionals (Kietzmann, Hermkens, McCarthy, \& Silvestre, 2011). Twitter has encountered with this development since its inception in the year 2006. At present more than 145 million users post on average 90 million message or "tweets" per day about their opinion, feelings, and daily activities. In turn, other users comment on a tweet and in doing so remain connected with other users. LinkedIn is treated more like a professional network that focuses on communication with professionals (Kietzmann et al., 2011).

The definition of social media is changing as the application are offering new features and contents. At present, social media is portraying beyond its casual functionality like sending a message, uploading photos and updating a profile. It has been used as a virtual community, content sharing and application development platform (Gruzd, Staves, \& Wilk, 2011). Social media comes as a new platform offering a socially connected educational place for researchers, students and other learned people. In the study of Friesen and Lowe (2012), social media use has been analysed in the context of media alteration endeavouring to measure the ability to fulfil the significant part of learning. According to Gikas and Grant (2013), though some inconvenience such as inattentiveness and distraction persist, student use of social networking sites in the classroom produces some positive outputs like information gathering and the availability of teaching materials. According to Sheldon (2008), the main for social media use by young adults is communicating with acquaintances. Entertainment and spending time are other reasons for using social media. A study on Facebook users by Quan-Haase and Young (2010) revealed that convenient ways of contacting family and friends drive the users to surf social media. A wide range of studies found Facebook as the most used instructional tool in university classrooms. Irwin, Ball, Desbrow, and Leveritt (2012) focused on the activities of Facebook pages for four university courses where 78 per cent of respondents regarded Facebook as an effective tool for learning. According to the study, with the perceived benefits of increasing interaction, participation in the course lecture, and posting lecture notes, Facebook was found as the most effectively used social media.

Ophus and Abbitt (2009) reported similar results regarding the students' opinion of Facebook utility. Students in a survey on biology course identified that communicating with students (95.5 per cent), viewing schedule ( 82.8 per cent) and access to materials (86.3 per cent) were the outcomes of using social media. McCarthy (2010) suggested that Facebook could be used in a combined learning environment. In a study of 120 architecture students, 95 per cent of respondents 
agreed that Facebook was a great help to build peer relationship through the interactive discussions and engagement with peers in an assessment task of a virtual classroom. In contrast, a study on 213 British students found that Facebook can be used for social learning process but in informal environments. A survey of 300 randomly chosen students from University Sains Malaysia by Kabilan, Ahmad, and Abidin (2010) found that 74 per cent students agreed that Facebook could be treated as useful media for learning and getting motivated to learn and communicate in English as a second language.

Other social media sites like Twitter were also examined. A sample of 125 respondents was assessed through the use of Twitter where the engagement of educational activities such as book discussion, class reminders, asking questions, conversations after class were found (Junco, Heiberger \& Loken, 2011). However, communication is not only the factor of social media use. For instance, an exploration of social media use by M-Almadhoun, Lai, Dominic, and Dhanapal (2012) on Malaysian University students found that 61.9 per cent of students use social media for searching information and 52.8 per cent use social media for educational purposes. Furthermore, online social media helps to foster formal and informal learning among undergraduate students, as found in the study of the Cyber University of South Korea. They use social media for connecting with friends (24.38 per cent), for discussing class projects (10.33 per cent), for keeping in touch with people (9.96 per cent) and for professional networking (10.14 per cent) (Yoo \& Kim, 2013).

Though social media is regarded as a social interaction tool, with proper usage, this social networking tool can be accessed for teaching and learning (Tess, 2013). The rapid increase in the use of social media in higher education among undergraduate students is well-documented. However, there are mixed results in the case of Facebook usage and its outcome. Some studies measured the output of learning using academic result GPA and some use other variables such as selfesteem, content in university activities, and sociability with other students in the university (Tess, 2013). For instance, Sapsani and Tselios (2017) analysed the Facebook use from the perspective of student involvement, amount of time spent, engagement in co-curricular activities and performance in academia, and found that access of Facebook was positively related with student preparation for the class.

Concerning social media use for the purpose of academic performance, Khan et al. (2016) study of university accounting students revealed a significant association between social media use and student grades. Different studies empirically tried to find the link between university students' social media use and academic performance. In a study of Egyptian undergraduate students, Sobaih, Moustafa, Ghandforoush, and Khan (2016) found that social media holds significant value for academic-related activities. According to Davis III, DeilAmen, Rios-Aguilar, and González Canche (2012), Facebook and other social media platforms opened a new horizon of learning with prompt interaction between faculty and students.

Nonetheless, Davis et al. (2012) found that engaging and involving students through social media can yield more positive results to fulfil the objectives of promoting education. For achieving a collaborative learning environment, social 
media plays a vital role by improving academic performance (Al-rahmi, Othman, Yusof, \& Musa, 2015). There is also evidence that social media tools are used for reducing students' anxiety by avoiding the situation of raising questions in front of their colleagues (Wheeler, Yeomans, \& Wheeier, 2008).

Numerous studies have investigated the relationship between social media use on university students' academic outcome and psychological state. Saha and Karpinski (2016) examined the link between 331 international students' psychological happiness and general social media use and academic performance to find that social media and Skype were positively associated with satisfaction and experience with life and ultimately impacted academic performance.

Liu, Kirschner, and Karpinski (2017) found a negative association between the use of social networking site and academic performance through GPA, whereas a positive relationship between the use of social networking site and language test was observed. The study found more intense negative relationship among the female college students. Alwagait, Shahzad, and Alim (2015) surveyed the GPA scored of Saudi Arabian undergraduate students and the time spent weekly on social media where no linear association was found between social media usage and GPA score. Among 108 responses, the result demonstrated that due to time management, students were negatively affected. Although some of the studies prefer to introduce the social media in the classroom, the study of Leyrer-Jackson and Wilson (2018) suggested not to incorporate social media in the classroom, especially in the field of biological science as the survey of 234 participants found a negative correlation between the amount of time spent on social media and GPA.

Some studies contain indifferent results where usage and non-usage of social media Facebook does not result in significant differences. For instance, Pasek and Hargittai (2009) found no change of academic performance due to the use of social media. Similarly, Dyson, Vickers, Turtle, Cowan, and Tassone (2015) explored a study where a Facebook group was established within an introductory psychology class to disseminate study materials and found no link between Facebook use and student involvement in course understanding.

Other studies explored different outcomes from the use of social media whereby factors other than GPA were associated with students' academic matters. For instance, Dabbagh and Kitsantas (2012) suggested in autonomous and informal settings that social media influences high levels of self-motivation among students. In contrast, Dyson et al. (2015) studied the association of social media use and academic task completion. The result showed that students involved in social media usually took longer to complete tasks than those who did not engage in these activities.

In analysing the benefits of using social media from the context of accounting education, most of the studies found the relevance of the usage. Accounting requires a medium to communicate the financial results to the respective stakeholders (Lee, Chen, \& Chan, 2017). In that sense, access to social media and communication are relevant. Social media such as Twitter and LinkedIn allow the users to cope with virtual communication systems in this age of information technology (Stone, 2012). Additionally, through social media people become accustomed to the culture of providing instant feedback with online chats and real-time messaging. These features are compatible with the learning objectives of 
accounting discipline, where financial information needs to be exchanged to the stakeholders in a timely manner (Lodhia, Stone, \& Parker, 2016).

As regards to the accounting education of university students, Stainbank and Gurr (2016) assessed the use of social media platforms on the students of first-year accounting course at a South African university where they found the networking site is mostly used for career information, not for communication and teaching, learning. On the other hand, some studies found resistance to using social media. For instance, Watty, McKay, and Ngo (2016) interviewed 93 per cent of the accounting faculty at an Australian university. In the finding, reluctance to incorporate social media in their curriculum and teaching method was discovered as a key constraint to technology acceptance and use.

In other branches of accounting such as management accounting, Holmes and Rasmussen (2018) conducted a survey to determine if using Pinterest to share online-based materials with their friends improved the interest to learn management accounting course. Evidence projected that using Pinterest for assignment completion significantly improved the understanding capability of the course topics. Student responses also denoted that the assignment completion through Pinterest ensured a positive impact on enhancing interest to learn managerial accounting. In these studies, different methods were used to assess the social media use outcome in academia. For instance, in the study of Leyrer-Jackson and Wilson (2018), Pearson's correlation was used to find the correlation between the number of social media website subscribers and the time spent on using social media. The social media use and the academic outcome was assessed through a frequency table where percentage results were prevalent. Most of the studies focused on the relationship of social media use and educational outcome in general and did not concentrate on a particular subject (Piotrowski, 2015; González, Gasco, \& Llopis, 2016; Yu, Shi, \& Cao, 2019; Mingle \& Adams, 2015).

As regards of the subject specificity, the interest and satisfaction of learning accounting course was measured through the use of social media. However, the above studies did not focus on the relationship between different academic use of social media and the current CGPA in accounting. In Bangladesh, studies of social media use are limited. For instance, Sajid (2016) studied the application of social media in marketing promotional activities in Bangladesh. The analysis rarely concentrates on disciplines outside of marketing. Therefore, the opportunity is available to further explore the academic-related engagement of students through social media. The current study focuses on the accounting literature by analysing how accounting undergraduate students use online social media to improve their academic performance.

After analysing the literature, this study designed a research model connecting social media usage and academic performance that was put in the questionnaire and surveyed afterwards. After that, factor loading was applied to the statements of the questionnaire based on the academic uses of social media to find the latent variables or dominating factors. These dominating factors were used as a path analytical framework where the impact of usage of social media on academic output was analysed. Overall, the paper investigated the following research questions after reviewing the previous studies: (RQ1) What are the latent variables and dominating factors of the academic usage of social media that influence 
academic performance? (RQ2) Do the latent variables of social media use have a positive relationship with the academic performance of undergraduate accounting students in Bangladesh? (RQ3) If positive, which social media usage factor has greater correlation with academic performance?

\section{Research Methodology}

\subsection{Sample and Statistical Procedure}

Undergraduate students from the accounting departments of different universities were taken as the participants of the study based on their exposure to and acceptance of social media. In Table 1 lists the number and gender of the accounting department students of under graduation level from different universities who completed the survey. In total, 180 students from the Bachelor of Business Administration (major in accounting) completed the survey. In the survey, if one-third of the questions were not answered, that questionnaire was discarded. Following the proposition, the usable responses for analysis received from 154 completed questionnaires which represented an overall response rate of 86 per cent. In addition, the academic year of the students was disclosed in Table 2 where it was observed that the majority of the respondents were in their final academic year.

Table 1. Profile of the respondents

\begin{tabular}{|c|c|c|c|c|}
\hline & & Male & Female & Total \\
\hline Bangladesh University of Professionals & & 15 & 21 & 36 \\
\hline North South University & & 12 & 18 & 30 \\
\hline Brac University & & 17 & 12 & 29 \\
\hline Dhaka University & & 17 & 18 & 35 \\
\hline \multirow[t]{2}{*}{ East West University } & & 14 & 10 & 24 \\
\hline & Total & 75 & 79 & 154 \\
\hline
\end{tabular}

Table 2. Academic Year

\begin{tabular}{lc}
\hline & Frequency (Percentage) \\
\hline 1 st year $2^{\text {nd }}$ semester & $32(21)$ \\
$2^{\text {nd }}$ year $2^{\text {nd }}$ semester & $42(27)$ \\
$3^{\text {rd }}$ year $1^{\text {st }}$ semester & $16(10)$ \\
$4^{\text {th }}$ year $1^{\text {st }}$ semester & $64(42)$ \\
\hline
\end{tabular}

\section{The Research Instrument}

\subsection{Variable Measurement}

5.1.1. Social media use

Academic usage of social media was analysed based on the questionnaire of 16 statements on which the Likert scale approach was used, where 1 represents 'Never' and 5 represents 'Always'. Khan et al., (2016) developed questions to evaluate undergraduate students' social media use pattern. Multiple questions which reflect the use of social media in academic activities. In this study, some questions are incorporated from their research. Other items were also selected from Lei and Zhao (2007). Based on these studies, the survey questionnaire was constructed. 


\subsubsection{Academic performance}

Factor loading was applied to identify the dominating factors to assess social media use that enhance academic performance. In Bangladesh, the four-point grade is used to represent the ungraduated student result. The academic performance was evaluated based on this CGPA measure.

\subsection{Data Analysis}

The methodology involves identifying the possible dimensions / constructs for social media usage from the previous literature. Then the study is set to examine the dominating factors by applying factor loading. For addressing the prime objective, use of social media and academic performance, data analysis software for statistics and data science: STATA was employed. First, the exploratory factor analysis was conducted to explore the best possible groups. After identifying groups, each group has been named or categorised, that are used as latent variables for analysing structural path analysis. Finally, the structural path model is measured to find the impact of social media use on CGPA. The measurement scale reliability was also assessed by Cronbach alpha. The three steps data analysis was followed: Step 1: An Exploratory Factor Analysis (EFA) along with varimax rotation was employed to find the latent variables. Step 2: Confirmatory factor analysis was performed to analyse whether the latent constructs provides a goodness-of-fit of the model. Step 3: The association between social media use and academic performance was evaluated using structural analysis. These three steps were introduced in the following ways.

\subsubsection{Exploratory Factor analysis}

First, exploratory factor analysis was examined to "determine whether the majority of the variance can be accounted for by one general factor" (Podsakoff, MacKenzie, Lee, \& Podsakoff, 2003). The result of the factor loading of measurement item SM3 was less than .5. Therefore, it is excluded from the measurement model. The exclusion confirms that all the other measurement items in each variable represent one factor, thus ensure convergent validity. For the test of reliability among the Likert questions reliability coefficients, i.e., Cronbach's alpha values were determined and helped determine whether the scale is reliable or not.

Table 3. Reliability Statistics

\begin{tabular}{lll}
\hline Cronbach's Alpha & Cronbach's Alpha Based on Standardised Items & N of Items \\
\hline .820 & .827 & 14 \\
\hline
\end{tabular}

From the Table 3 above, it is observed that the Cronbach's alpha value is .820 , which exceeded the prescribed .70 level thereby demonstrating a high level of internal consistency in the scale with this specific sample (Garver and Mentzer, 1999). For finding the predominant factors which influence students to use social media for educational purposes, a factor analysis was conducted on 14 statements. The main objective of this analysis is to reduce the variables into categorical factors regarding the use of social media for education purpose. 
To examine the adequacy of the sample and the suitability of data for factor analysis, Kaiser Meyer-Olkin (KMO) and Bartlett's test was executed. Sampling adequacy is needed to get the information regarding the grouping of survey items. The measurement of sampling adequacy evaluate the strength of the correlation of different items in the exploratory factor analysis correlation matrix (Burton and Mazerolle, 2011).

Table 4. KMO and Bartlett's Test

\begin{tabular}{lll}
\hline \multicolumn{2}{l}{ Kaiser-Meyer-Olkin Measure of Sampling Adequacy. } & .737 \\
\hline & Approx. Chi-Square & 731.015 \\
\hline Bartlett's Test of Sphericity & df & 91 \\
\hline & Sig. & .000 \\
\hline
\end{tabular}

KMO correlation above .60-.70 is considered adequate for analysing the EFA output. According to the KMO and Bartlett test result, all the variables regarding the academic usage of social media are interrelated as the level of significance is $.000<.05$ or .01 . Therefore, based on the interrelation of these variables, factor analysis could be employed.

In Table 4, the KMO measure of sampling adequacy is .737 and Bartlett's Test of Sphericity with appropriate chi-square is 731.015, which are statistically significant at the 5 per cent level. This indicates that the sample is adequate for the factor segmentation and 14 variables form the normal distribution. Fixed factor analysis is applied to minimise the variable into five dimensions.

The factors are shown in rotated factor loadings in the Appendix. The correlations between observed variables and the factors were suppressed above \pm .50 , meaning that those observed variables have correlation less than .50 with the extracted factors are ignored. After having the result from the analysis, 14 variables were minimised into 05 key factors. This leads to the categorising of variables displayed in Table 1.

By observing rotated factor loadings, it was observed that five factors influence the use of social media for academic purposes. Here, Factor 1=f(OS9, OS8, OS15, OS4) incorporates the variables that are related to group discussion, sharing course materials, discussion of academic matters with privacy and confidentiality and taking exam preparation which may be labelled as "online sharing". In Factor $2=f(C C 1, C C 16)$ includes the variables which are related to the completion of assignments and help for class presentation which may be labelled as "Completion of course tasks". Besides that, Factor $3=\mathrm{f}(\mathrm{AC} 11, \mathrm{AC} 7, \mathrm{AC} 5, \mathrm{AC} 10)$ integrates the benefits from academic blogger, comprehension of an academic topic, remain up to date with study materials, enhancement of the spirit among university group members which may be labelled as "academic comprehension". Moreover, in Factor 4=f(AI13, AI14) engagement in different club-related activities of the university, posting opinion in any academic-related topic may be labelled as "academic involvement". Lastly, in factor $5=\mathrm{f}(\mathrm{PTS12}$, PTS2), communicating with academic instructors of the particular subject and receive help for academic projects of different courses may be categorised as "personal tutorial support".

Principal component factor was analysed through the varimax rotation method. The result of the factors showed that five factors explain 70.66 per cent of 
the variance of the variables, with 30.22 per cent by the first extracted factor. Therefore, no evidence found that a single factor appeared, or any factor explained most of the variance. Thus, in survey variables, common method bias is not a serious problem.

\subsubsection{Confirmatory Factor Analysis}

To support construct validity, convergent validity was assessed to ensure all items measure the construct as intended (Hair et al., 2010). According to Hair et al. (2010), for assessing convergent validity, the factor loadings, composite reliability (CR) and average variance extracted (AVE) must be identified. As regards Hair et al. (2010) recommendation, the loadings (the item reliability on the construct) for all variables in this study were found significant as the suggested value of .5 was exceeded. The AVE discloses the total amount of variance in the variables accounted for by the latent construct, which was greater than the recommended value .5 ranged from .505 to .559 by Hair et al. (2010). To specify the latent construct, CR values were used, which was between .702 and .803, as shown in Table 5, where the suggested cut-off value is .7.

Table 5. Instrument reliability and validity

\begin{tabular}{|c|c|c|c|c|}
\hline Constructs & Items & Loading & $\mathrm{AVE}^{\mathrm{a}}$ & $\mathrm{CR}^{\mathrm{b}}$ \\
\hline \multirow[t]{4}{*}{ Online Sharing } & OS1 & .92 & .514 & .803 \\
\hline & OS2 & .67 & & \\
\hline & OS3 & .66 & & \\
\hline & OS4 & .57 & & \\
\hline \multirow[t]{2}{*}{ Completion of course task } & $\mathrm{CC} 1$ & .79 & .543 & .702 \\
\hline & CC2 & .68 & & \\
\hline \multirow{4}{*}{ Academic Comprehension } & $\mathrm{AC} 1$ & .75 & .505 & .800 \\
\hline & $\mathrm{AC} 2$ & .83 & & \\
\hline & $\mathrm{AC} 3$ & .63 & & \\
\hline & $\mathrm{AC} 4$ & .61 & & \\
\hline \multirow[t]{2}{*}{ Academic Involvement } & AI1 & .81 & .552 & .709 \\
\hline & AI2 & .67 & & \\
\hline \multirow[t]{2}{*}{ Personal Tutorial Support } & PTS1 & .89 & .559 & .707 \\
\hline & PTS2 & .57 & & \\
\hline
\end{tabular}

a presents the Average Variance Extracted (AVE) $=$ (summation of the square of the factor loadings)/ [(summation of the square of the factor loadings) + (summation of the error variances)]. ${ }^{b}$ presents the Composite Reliability $(\mathrm{CR})=$ (square of the summation of the factor loadings)/ [(square of the summation of the factor loadings) + (square of the summation of the error variances)].

\subsubsection{Discriminant Validity}

Afterwards, discriminant validity was assessed, which measures the degree to which a measurement reflects some other constructs. It measured the degree to which a construct differs from other constructs. According to Fornell and Larcker (1981), in any two constructs, the correlations among items should be lower than the square root of the AVE shared by items within a construct. For acceptable discriminant validity, each indicator evaluates its intended constructs. Furthermore, the shared AVE between a construct and its measures should be 
greater than the AVE shared by the constructs in the model. In Table 6, satisfactory discriminant validity was presented of the present study.

Table 6. Discriminant Validity of the Constructs

\begin{tabular}{cccccc}
\hline & $O S$ & $C C$ & $A C$ & $A I$ & $P T S$ \\
\hline$O S$ & .717 & & & & \\
$C C$ & .16 & .737 & & & \\
$A C$ & -.43 & .26 & .711 & & \\
$A I$ & .36 & -.31 & .026 & .743 & .745 \\
PTS & -.046 & .09 & -.15 & -.17 & \\
\hline
\end{tabular}

$O S$ is online sharing, $C C$ is completion of course task, $A C$ is academic comprehension, $A I$ is academic Involvement; PTS is Personal Tutorial Support. Diagonal elements are put down to indicate the AVE between the constructs and their measures. While Off diagonal elements are used to explain the correlations between constructs.

\section{Result}

This study investigated the effect of using social media on the academic performance of undergraduate accounting students in Bangladesh. In this respect, this study analysed the dominating factors of social media use for academic purposes and categorised the five key variables for using social media. These are online sharing, completion of course task, academic comprehension, academic involvement and personal tutorial support which served the requirement of RQ1. In summary, the RQ2 results of the structural path analysis disclosed that the effect of the three factors of using social media for academic purposes had significant results. where online sharing $(b=.409, p<.05)$, completion of course task $(b=-.819$, $p<.01)$ and academic comprehension $(b=.381, p<.05)$ were significantly related to academic performance (CGPA). Furthermore, both academic involvement $(b=-$ $.112, p>.05)$ and personal tutorial support $(b=-.045, p>.05)$ were not significantly associated with student academic performance (CGPA). As for RQ3, the findings revealed that the out of five only two factors of using social media for academic purposes had the most positive influence on academic performance. The study explained 62.3 per cent variance of CGPA by five factors of using social media. The outcome of the structural model is displayed in Table 7.

Table 7. Structural Model (Path Analysis) result

\begin{tabular}{|c|c|c|c|c|}
\hline Path & Std. beta & Std Error & $P$-value & Decision \\
\hline Online sharing > CGPA & .409 & .200 & $.04^{*}$ & Supported \\
\hline Completion of course task > CGPA & -.819 & 908 & $.000^{* *}$ & Supported \\
\hline Academic Comprehension > CGPA & 381 & 193 & $.048^{*}$ & Supported \\
\hline Academic Involvement > CGPA & -.112 & 201 & .574 & $\begin{array}{c}\text { Not } \\
\text { Supported }\end{array}$ \\
\hline Personal Tutorial Support $>$ CGPA & -.045 & .194 & .814 & $\begin{array}{c}\text { Not } \\
\text { Supported }\end{array}$ \\
\hline
\end{tabular}

Notes: ${ }^{*} p<.05,{ }^{* *} p<.01$

The result in Table 7 was used to depict the relationship between the factors and academic performance. In Figure 1, the relationship of academic performance with five academic-related factors was presented where two factors (online sharing, academic comprehension) had a positive influence on CGPA and one factor (completion of course task) had a negative influence on CGPA. In addition, 
two factors (academic comprehension, personal tutorial support) did not have any impact on academic performance (CGPA).

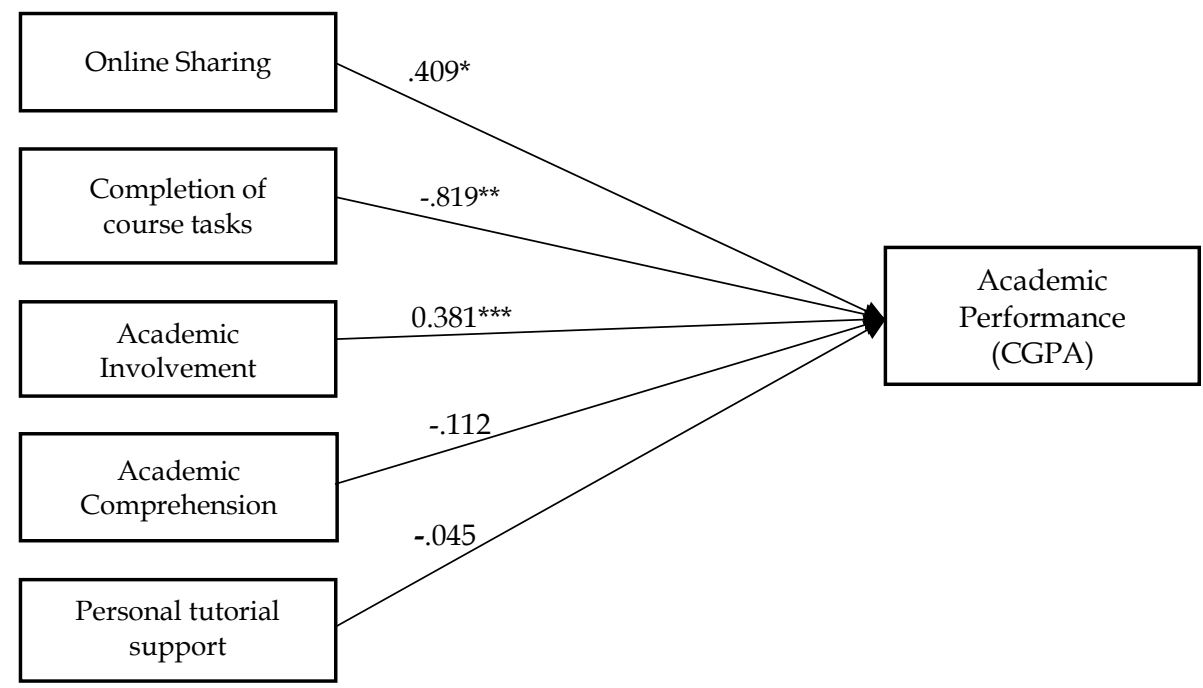

Figure 1. Structural Model outcome effect of these factors on CGPA

\section{Discussion}

The main purpose of this paper is to study the relationship between social media academic use (i.e., online sharing, completion of course task, academic comprehension, academic involvement and personal tutorial support) and academic outcome through CGPA. The results of the structural path analysis disclosed that the effect of the two factors (online sharing and academic comprehension) of using social media for academic purposes had significant positive results. On the other hand, completion of course task affected the academic performance negatively.

Previous researchers had assessed hours of social media use as a dependent variable to assess academic performance (González et al., 2016; Yoo and Kim, 2013). This study examined the factors to categorise the academic usage of social media which explains that, when the students use social media as an online sharing platform and for comprehending any academic topic, accounting undergraduate students can have positive academic performance. On the other hand, for completion of course tasks such as assignment and presentation, the students particularly the accounting students can have significant negative academic performance, and in the case of academic involvement and getting personal tutorial support from social media, the involvement portrays nonsignificant negative outcome. Thus, the present findings were similar to the results of previous studies.

The results showed that online academic material sharing impacts academic outcome (CGPA) positively. They indicated that through the platform of social media students send assignments, exercises, books, notes and thus students can encounter positive result in their studies and ultimately it reflects in their 
academic performance (CGPA). Alwagait et al. (2015) found a positive correlation between social media use and academic outcome measured through GPA. The justification of the findings could be that students spend a substantial amount of time on the social media platform, and experience instant and fast distribution of files and information. Therefore, the conclusion can be made that undergraduate accounting students use social media for sharing purposes, and it positively influences their academic outcome.

On the other hand, the findings stressed that using social media for various course-related tasks such as assignment completion and presentation completion influence the academic outcome (CGPA) negatively. The particular finding is supported by Dyson et al.'s (2015) study of the association of social media use and academic task completion where the result showed that students who involved in social media usually took longer to complete tasks than those who did not engage in these activities. Thus, the accounting students do not usually benefit from using social media platform in the case of assignment and presentation completion.

The present findings were also aligned with the finding that using social media for academic comprehension is positively related to academic performance. Previously, Bowman, Westerman, and Claus (2012) examined the ability of student comprehension and the use of social media where a negative outcome emerged in the efficiency of student learning of new information but not in the understanding of study materials. This denotes that social media features can be effective to get help to understand a given topic.

The present findings from the survey on the accounting undergraduate students in Bangladesh had shown that Facebook and other social media offer a friendly atmosphere to the students for exchanging instant feedback and comment on any academic topic which promoted the group work effort. This helped them to get assistance apprehending complex academic topics and remain aware of recent academic materials. As regards the group contribution, through social media such as Facebook and YouTube, students can follow and subscribe to an academic blogger to connect with the particular community's engagements.

In regards to academic involvement as categorised in terms of the engagement of different club-related activities, accounting students in Bangladesh were not active in using social media thus a non-significant negative relationship was found in the case of social media use and academic involvement. The findings were aligned with the study of Mathur, Nathani, Sharma, Modi, and Arora (2019) who revealed that knowledge enhancement was a secondary purpose of using social media, and over-usage of Facebook affected student involvement in different academic activities. Likewise, in the case of personal tutorial help from academic instructor and assistance in a project-related topic, the academic outcome and use of social media come with a non-significant negative outcome. In the study of Khan et al. (2016), it was disclosed out of 93 respondents, only 17 per cent had used social media for tutorial task completion.

\section{Conclusion}

Social media is perceived as an informal learning platform among the students. However, due to the proliferation in the use of social media, students discover the media is more promising in academia. This particular study assessed the usage 
pattern of social media by undergraduate accounting students, along with the effect of social media on academic performance. Accounting students engage actively in social media for academic-related tasks. With Facebook as the predominant media, the accounting students mostly use social media for sharing and exchanging course-related materials, academic information, and to comprehend complex academic topics. The relationship of using social media for online sharing and comprehending academic matter was positive. Therefore, if social media is taken as a formal platform and is incorporated in university academic tasks, it would help students. On the other hand, for personal tutorial support and project-related help, the relationship between the usage of social media and outcome was negative. Therefore, if the communication between students and tutors are enhanced through the social media platform, then the relationship would be more pronounced, and the use of social media for academic understanding would be more effective. Also, for the completion of course tasks, the significance of the relationship was negative. The reason could be the inaccuracy of information shared via social media or time management in the vast content of social media hamper the successful completion of the course tasks. However, in different studies, this particular factor appeared as beneficial for the students (Liu et al., 2017; Pempek et al., 2009; Lei \& Zhao, 2007). Therefore, if proper workshops are arranged to ensure effective use of social media for a formal learning environment, the students as a stakeholder of this platform would receive more assistance. In conclusion, the study framed the usage pattern and factors that influence students to use social media for academic purposes. Though the study measured the academic performance through the grade point (CGPA), there is a scope for future research to assess the relationship with other qualitative factors such as self-confidence, communication, and the personality of the students.

\section{References}

Al-rahmi, W.M., Othman, M.S., Yusof, L.M., \& Musa, M.A. (2015). Using social media as a tool for improving academic performance through collaborative learning in Malaysian higher education. Review of European Studies, 7(3), 265-275. https:/ / doi.org/10.5539/res.v7n3p265

Alwagait, E., Shahzad, B., \& Alim, S. (2015). Impact of social media usage on students' academic performance in Saudi Arabia. Computers in Human Behavior, 51, 1092-1097. https://doi.org/10.1016/j.chb.2014.09.028

Andreshak, N. (2020, January 1). Facebook users in Bangladesh. NapoleonCat.Com. https://napoleoncat.com

Blackshaw, P., \& Nazzaro, M. (2006). Consumer generated media (CGM) 101: Word-of-mouth in the age of web-fortified consumer. A Nielsen BuzzMetrics White Paper. New York. https:// ci.nii.ac.jp/naid/10029627396/\#cit

Bowman, N.D., Westerman, D.K., \& Claus, C.J. (2012). How demanding is social media: Understanding social media diets as a function of perceived costs and benefits-A rational actor perspective. Computers in Human Behavior, 28(6), 2298-2305. https://doi.org/10.1016/j.chb.2012.06.037

Boyd, D.M., \& Ellison, N.B. (2007). Social network sites: Definition, history, and scholarship. Journal of Computer-Mediated Communication, 13(1), 210-230. https:// doi.org/10.1111/j.10836101.2007.00393.x

Burton, L.J., \& Mazerolle, S.M. (2011). Survey instrument validity part I: Principles of survey instrument development and validation in athletic training education research. Athletic $\begin{array}{llll}\text { Training } \quad \text { Education } & \text { 27 } & \text { Journal, }\end{array}$ https://www.natajournals.org/doi/abs/10.4085/1947-380X-6.1.27 
Dabbagh, N., \& Kitsantas, A. (2012). Personal Learning Environments, social media, and selfregulated learning: A natural formula for connecting formal and informal learning. The Internet and Higher Education, 15(1), 3-8. https:/ / doi.org/10.1016/j.iheduc.2011.06.002

Davis III, C.H., Deil-Amen, R., Rios-Aguilar, C., \& Gonzalez Canche, M.S. (2012). Social Media in Higher Education: A literature review and research directions. The Center for the Study of Higher Education at The University of Arizona: Claremont Graduate University. https://www.academia.edu/1220569/Social_Media_in_Higher_Education_A_Literature_R eview_and_Research_Directions

Dyson, B., Vickers, K., Turtle, J., Cowan, S., \& Tassone, A. (2015). Evaluating the use of Facebook to increase student engagement and understanding in lecture-based classes. Higher Education, 69(2), 303-313. https://doi.org/10.1007/s10734-014-9776-3

Fornell, C., \& Larcker, D.F. (1981). Evaluating structural equation models with unobservable variables and measurement error. Journal of Marketing Research, 18(1), 39-50. https:// doi.org/10.1177/002224378101800104

Friesen, N., \& Lowe, S. (2012). The questionable promise of social media for education: Connective learning and the commercial imperative. Journal of Computer Assisted Learning, 28(3), 183-194. https:// doi.org/10.1111/j.1365-2729.2011.00426.x

Garver, M.S., \& Mentzer, J.T. (1999). Logistics research methods: Employing structural equation modeling to test for construct validity. Journal of Business Logistics, 20(1), 33-57. https://search.proquest.com/openview/a778d630df6747e2918f1527a34cbd76/1?pqorigsite $=$ gscholar\&cbl $=36584$

Gikas, J., \& Grant, M.M. (2013). Mobile computing devices in higher education: Student perspectives on learning with cellphones, smartphones \& social media. The Internet and Higher Education, 19, 18-26. https://doi.org/10.1016/j.iheduc.2013.06.002

González, M.R., Gasco, J., \& Llopis, J. (2016). Facebook and academic performance: A positive outcome. The Anthropologist, 23(1-2), 59-67.https:// doi.org/10.1080/09720073.2016.11891924

Gruzd, A., Staves, K., \& Wilk, A. (2011). Tenure and promotion in the age of online social media. Proceedings of the American Society for Information Science and Technology, 48(1), 1-9. https:// doi.org/10.1002/meet.2011.14504801154

Hair, J.F., Black, W.C., Babin, B.J., \& Anderson, R.E. (2010). Multivariate data analysis: Global edition. NJ: Pearson Higher Education Upper Saddle River.

Holmes, A.F., \& Rasmussen, S. J. (2018). Using Pinterest to stimulate student engagement, interest, and learning in managerial accounting courses. Journal of Accounting Education, 43, 43-56. https:// doi.org/10.1016/j.jaccedu.2018.03.001

Irwin, C., Ball, L., Desbrow, B., \& Leveritt, M. (2012). Students' perceptions of using Facebook as an interactive learning resource at university. Australasian Journal of Educational Technology, 28(7), 8-11. https://doi.org/10.14742/ajet.798

Junco, R., Heiberger, G., \& Loken, E. (2011). The effect of Twitter on college student engagement and grades. Journal of Computer Assisted Learning, 27(2), 119-132. https://doi.org/10.1111/j.1365-2729.2010.00387.x

Kabilan, M.K., Ahmad, N., \& Abidin, M.J.Z. (2010). Facebook: An online environment for learning of English in institutions of higher education? The Internet and Higher Education, 13(4), 179187. https://doi.org/10.1016/j.iheduc.2010.07.003

Kaplan, A.M., \& Haenlein, M. (2010). Users of the world, unite! The challenges and opportunities of Social Media. Business Horizons, 53(1), 59-68. https:/ / doi.org/10.1016/j.bushor.2009.09.003

Khan, T., Kend, M., \& Robertson, S. (2016). Use of social media by university accounting students and its impact on learning outcomes. Accounting Education, 25(6), 534-567. https://doi.org/10.1080/09639284.2016.1230880

Kietzmann, J.H., Hermkens, K., McCarthy, I.P., \& Silvestre, B.S. (2011). Social media? Get serious! Understanding the functional building blocks of social media. Business Horizons, 54(3), 241251. https://doi.org/10.1016/j.bushor.2011.01.005

Lau, W.W. (2017). Effects of social media usage and social media multitasking on the academic performance of university students. Computers in Human Behavior, 68, 286-291. https:// doi.org/10.1016/j.chb.2016.11.043 
Lee, F.L., Chen, H.-T., \& Chan, M. (2017). Social media use and university students' participation in a large-scale protest campaign: The case of Hong Kong's Umbrella Movement. Telematics and Informatics, 34(2), 457-469. https:// doi.org/10.1016/j.tele.2016.08.005

Lei, J., \& Zhao, Y. (2007). Technology uses and student achievement: A longitudinal study. Computers and Education, 49(2), 284-296. https:// doi.org/10.1016/j.compedu.2005.06.013

Lenhart, A., Purcell, K., Smith, A., \& Zickuhr, K. (2010). Social Media \& Mobile Internet Use among Teens and Young Adults. Millennials. Pew Internet \& American Life Project.

Leyrer-Jackson, J.M., \& Wilson, A.K. (2018). The associations between social-media use and academic performance among undergraduate students in biology. Journal of Biological Education, 52(2), 221-230. https://doi.org/10.1080/00219266.2017.1307246

Liu, D., Kirschner, P.A., \& Karpinski, A.C. (2017). A meta-analysis of the relationship of academic performance and Social Network Site use among adolescents and young adults. Computers in Human Behavior, 77, 148-157. https:// doi.org/10.1016/j.chb.2017.08.039

Lodhia, S., Stone, G., \& Parker, L. (2016). Strategising for social media: A public accounting $\begin{array}{lllll}\text { practice } & \text { perspective. } & \text { Australia, 122- }\end{array}$ 125.https://www.researchgate.net/profile/Sumit_Lodhia/publication/302378686

M-Almadhoun, N., Lai, F.W., Dominic, D., \& Dhanapal, P. (2012). An examination of social networking sites uasage among the students in the Malaysian universities. Proceedings of the International Conference on Management, Economics and Finance, Sarawak, Malaysia, Oct. 15-16, 2012.

Mathur, G., Nathani, N., Sharma, A., Modi, D., \& Arora, G. (2019). Impact of Facebook Usage on Students' Involvement in Studies. Proceedings of 10th International Conference on Digital Strategies for Organizational Success. http://dx.doi.org/10.2139/ssrn.3323784

McCarthy, J. (2010) ‘Blended learning environments: using social networking sites to enhance the first year experience', Australasian Journal of Educational Technology 26(6): 729-740. https:// doi.org/10.14742/ajet.1039

McFarlane, A. (1997). What are we and how did we get here?. In: A. McFarlane (Ed.). Information technology and authentic learning: realizing the potential of computers in the primary classroom. London, UK: Routledge.

Mingle, J., \& Adams, M. (2015). Social media network participation and academic performance in senior high schools in Ghana. Library Philosophy and Practice, 1.

Murad, M. (2017, April 15). Dhaka ranked second in number of active Facebook users. bdnews24.com. https://bdnews24.com

Ophus, J.D., \& Abbitt, J.T. (2009). Exploring the potential perceptions of social networking systems in university courses. Journal of Online Learning and Teaching, 5(4), 639-648. https://jolt.merlot.org/vol5no4/ophus_1209.pdf

Pasek, J., \& Hargittai, E. (2009). Facebook and academic performance: Reconciling a media sensation with data. First Monday, 14(5), 122-124. https:// doi.org/10.5210/fm.v14i5.2498

Pempek, T. A., Yermolayeva, Y. A. and Calvert, S. L. 2009. College students' social networking experiences on Facebook. Journal of Applied Developmental Psychology, 30(3): 227-238. https:// doi.org/10.1016/j.appdev.2008.12.010

Piotrowski, C. (2015). Emerging research on social media use in education: A study of dissertations. Research in Higher Education Journal, 27, 1-12.

Podsakoff, P.M., MacKenzie, S.B., Lee, J.-Y., \& Podsakoff, N.P. (2003). Common method biases in behavioral research: A critical review of the literature and recommended remedies. Journal of Applied Psychology, 88(5), 879-903. https:// doi.org/10.1037/0021-9010.88.5.879

Quan-Haase, A., \& Young, A.L. (2010). Uses and gratifications of social media: A comparison of Facebook and instant messaging. Bulletin of Science, Technology and Society, 30(5), 350-361. https://doi.org/10.1177/0270467610380009

Rahman, S. (2020, February 11). Number of internet subscribers reaches over 99 million. The Financial Express. https:// thefinancialexpress.com.bd

Saha, N., \& Karpinski, A. C. (2016). The influence of social media on international students' global life satisfaction and academic performance. In Campus support services, programs, and policies for international students (pp. 57-76). IGI Global. https://doi.org/10.4018/978-1-4666-97522.ch004 
Sajid SI (2016) Social Media and Its Role in Marketing. Business and Economics Journal, 7(1), 203207. http://dx.doi.org/10.4172/2151-6219.1000203

Sapsani, G., \& Tselios, N. (2017). Facebook use, personality characteristics and academic performance: A correlational study. ArXiv Preprint ArXiv:1703.04095.

Sheldon, P. (2008). The relationship between unwillingness-to-communicate and students' Facebook use. Journal of Media Psychology, 20(2), 67-75. https://doi.org/10.1027/18641105.20.2.67

Sobaih, A.E.E., Moustafa, M.A., Ghandforoush, P., \& Khan, M. (2016). To use or not to use? Social media in higher education in developing countries. Computers in Human Behavior, 58, 296-305. https://doi.org/10.1016/j.chb.2016.01.002

Sponcil, M., \& Gitimu, P. (2013). Use of social media by college students: Relationship to communication and self-concept. Journal of Technology Research, 4, 1-13. http://www.aabri.com/manuscripts/121214.pdf

Stainbank, L., \& Gurr, K.-L. (2016). The use of social media platforms in a first year accounting course: An exploratory study. Meditari Accountancy Research, 24(3), 318-340. https:// doi.org/10.1108/MEDAR-08-2015-0051

Stone, G. (2012). The effectiveness of newsletters in accountants' client relations with small business managers: An Australian qualitative study. Qualitative Research in Accounting and Management, 9(1), 21-43. https:// doi.org/10.1108/11766091211216097

Tess, P.A. (2013). The role of social media in higher education classes (real and virtual)-A literature review. Computers in Human Behavior, 29(5), A60-A68. https:// doi.org/10.1016/j.chb.2012.12.032

Watty, K., McKay, J., \& Ngo, L. (2016). Innovators or inhibitors? Accounting faculty resistance to new educational technologies in higher education. Journal of Accounting Education, 36, 1-15. https://doi.org/10.1016/j.jaccedu.2016.03.003

Wheeler, S., Yeomans, P., \& Wheeler, D. (2008). The good, the bad and the wiki: Evaluating student-generated content for collaborative learning. British Journal of Educational Technology, 39(6), 987-995. https://doi.org/10.1111/j.1467-8535.2007.00799.x

Yoo, S.J., \& Kim, S. (2013). How and why college students use Web 2. 0 applications: The role of social media in formal and informal learning. International Journal of Web Based Communities, 9(2), 174-187. https:// doi.org/10.1504/IJWBC.2013.053242

Yu, L., Shi, C., \& Cao, X. (2019, January). Understanding the effect of social media overload on academic performance: a stressor-strain-outcome perspective. In Proceedings of the 52nd Hawaii International Conference on System Sciences. http:// doi.org/10.24251/HICSS.2019.320 


\section{Appendix}

Table 1. Rotated factor loadings (Pattern Matrix)

\begin{tabular}{|c|c|c|c|c|c|c|}
\hline Items & Description & $\begin{array}{c}\text { Factor } \\
1\end{array}$ & $\begin{array}{l}\text { Factor } \\
2\end{array}$ & $\begin{array}{c}\text { Factor } \\
3\end{array}$ & $\begin{array}{c}\text { Factor } \\
4\end{array}$ & $\begin{array}{l}\text { Factor } \\
5\end{array}$ \\
\hline OS9 & $\begin{array}{l}\text { I use social media to have group } \\
\text { discussions with other members. }\end{array}$ & .92 & & & & \\
\hline OS8 & $\begin{array}{l}\text { I use social media to share course } \\
\text { materials with other students. }\end{array}$ & .67 & & & & \\
\hline OS15 & $\begin{array}{l}\text { I use social media to discuss any } \\
\text { academic matter privately and } \\
\text { confidentially. }\end{array}$ & .66 & & & & \\
\hline OS4 & $\begin{array}{l}\text { I use social media for taking } \\
\text { exam preparation with other } \\
\text { students. }\end{array}$ & .57 & & & & \\
\hline $\mathrm{CC} 1$ & $\begin{array}{l}\text { I use social media for completing } \\
\text { my assignment. }\end{array}$ & & .79 & & & \\
\hline CC6 & $\begin{array}{l}\text { I use social media to take } \\
\text { preparation for the course } \\
\text { presentation. }\end{array}$ & & .68 & & & \\
\hline AC11 & $\begin{array}{l}\text { I use social media to get benefits } \\
\text { from academic blogger. }\end{array}$ & & & .75 & & \\
\hline AC7 & $\begin{array}{l}\text { I use social media to comprehend } \\
\text { any academic topic. }\end{array}$ & & & .83 & & \\
\hline AC5 & $\begin{array}{l}\text { I use social media to remain up } \\
\text { to date with study materials. }\end{array}$ & & & .63 & & \\
\hline AC10 & $\begin{array}{l}\text { I use social media for enhancing } \\
\text { the spirit among university } \\
\text { group members. }\end{array}$ & & & .61 & & \\
\hline AI13 & $\begin{array}{l}\text { I use social media to get engaged } \\
\text { in different club related activities } \\
\text { of the university. }\end{array}$ & & & & .81 & \\
\hline AI14 & $\begin{array}{l}\text { I use social media to post my } \\
\text { opinion in any academic-related } \\
\text { topic. }\end{array}$ & & & & .67 & \\
\hline PTS12 & $\begin{array}{l}\text { I use social media for } \\
\text { communicating with academic } \\
\text { instructors of the particular } \\
\text { subject. }\end{array}$ & & & & & .89 \\
\hline PTS2 & $\begin{array}{l}\text { I use social media to get help for } \\
\text { academic projects of different } \\
\text { courses. }\end{array}$ & & & & & . 57 \\
\hline
\end{tabular}

